\title{
PENGARUH PENGAWASAN PIMPINAN TERHADAP DISIPLIN KERJA KARYAWAN PADA PABRIK MESIN INDUSTRI KECAMATAN GEGER KABUPATEN MADIUN
}

\author{
Zhendy Citra Larrynsia Wijanarko \\ Mahasiswa Prodi Pendidikan Ekonomi FPIPS IKIP PGRI Madiun \\ zhendy_citra57@gmail.com
}

\begin{abstract}
This study aims to determine Supervision Leadership in Plant Engineering Industry, to know Discipline Employees in Industry Machinery Factory, as well as to determine whether or not Influence Between Monitoring Employee Discipline Leader Against the Machine Factory Geger Madiun County Industrial District. This research uses design conclusive studies. Data collection using questionnaires, observation, documentation and data analysis using linear regression correlation test, $\mathrm{F}$ test and $\mathrm{t}$ test. The results showed that the supervisory leaders have influence at the same time a positive relationship to discipline employees working at Plant Engineering Geger Madiun County Industrial District. It can be seen from the results of linear regression analysis of $\mathrm{Y}=11.277+0.840 \mathrm{X}$. This means that if the leadership supervision increased by $1 \%$, the discipline of employees will increase by $0.840 \%$ if other factors held constant. Based on the hypothesis testing results obtained from the correlation test showed that rhitung is 0.6727 while the value rtabel at $\mathrm{N}=30$ is 0.361 . Thus $\mathrm{HO}$ is rejected, meaning that there is difference between the effect of supervision led to the discipline of employees at Plant Engineering Geger Madiun County Industrial District.
\end{abstract}

Keywords: Supervision Of Management, Employee Discipline

\begin{abstract}
Abstrak. Penelitian ini bertujuan untuk mengetahui Pengawasan Pimpinan pada Pabrik Mesin Industri, untuk mengetahui Disiplin Kerja Karyawan pada Pabrik Mesin Industri, serta untuk mengetahui ada atau tidaknya Pengaruh Antara Pengawasan Pimpinan Terhadap Disiplin Kerja Karyawan pada Pabrik Mesin Industri Kecamatan Geger Kabupaten Madiun. Penelitian ini menggunakan desain penelitian konklusif. Pengumpulan data menggunakan metode kuesioner, observasi, dokumentasi dan analisis data regresi linier dengan menggunakan uji korelasi, uji f dan uji t. Hasil penelitian menunjukkan bahwa pengawasan pimpinan mempunyai pengaruh sekaligus hubungan yang positif terhadap disiplin kerja karyawan pada Pabrik Mesin Industri Kecamatan Geger Kabupaten Madiun. Hal ini dapat dilihat dari hasil analisis regresi linier $\mathrm{Y}=11,277+0,840 \mathrm{X}$. Artinya apabila pengawasan pimpinan meningkat $1 \%$ maka disiplin kerja karyawan akan meningkat $0,840 \%$ apabila faktor lain dianggap tetap. Berdasarkan pengujian hipotesis diperoleh hasil dari uji korelasi yang menunjukkan bahwa $r_{\text {hitung }}$ adalah 0,6727 sedangkan nilai $r_{\text {tabel }}$ pada $\mathrm{N}=30$ adalah 0,361. Dengan demikian $\mathrm{H}_{0}$ ditolak, artinya ada beda pengaruh antara pengawasan pimpinan terhadap disiplin kerja karyawan pada Pabrik Mesin Industri Kecamatan Geger Kabupaten Madiun.
\end{abstract}

Kata kunci: Pengawasan Pimpinan, Disiplin Kerja Karyawan 


\section{PENDAHULUAN}

Di era globalisasi ini dalam rangka persaingan dunia usaha perusahaan harus memiliki sumber daya yang tangguh. Sumber daya yang dibutuhkan untuk menjalankan perusahaan tidak dapat dilihat sebagai bagian yang berdiri sendiri, tetapi harus dilihat sebagai satu kesatuan yang tangguh membentuk suatu sinergi. Dalam hal ini peran sumber daya manusia sangat menentukan.

Perusahaaan harus mampu mengoptimalkan dalam pengelolaan sumber daya yang dimilikinya tersebut, agar perusahaan dapat terus beroperasi, maka perusahaan perlu memperhatikan dan menciptakan disiplin kerja agar karyawan yang ada dalam perusahaan tersebut dapat bekerja dan mentaati peraturan-peraturan yang ada dalam perusahaan tersebut.

Menurut Handoko (2014: 359) pengawasan didefinisikan sebagai "proses untuk menjamin bahwa tujuan-tujuan organisasi dan manajemen tercapai. Ini berkenaan dengan cara-cara membuat kegiatan-kegiatan sesuai yang direncanakan."

Menurut Singodimedjo (dalam Edy Sutrisno., 2009: 89) "Orang yang paling tepat melaksanakan pengawasan terhadap disiplin ini tentulah atasan langsung para karyawan yang bersangkutan. Hal ini disebabkan para atasan langsung itulah yang paling tahu dan paling dekat dengan para karyawan yang ada dibawahnya.
Pengawasan yang dilaksanakan atasan langsung ini sering disebut WASKAT (Pengawasan Melekat). Pada tingkat mana pun ia berada, maka seorang pemimpin bertanggung jawab melaksanakan pengawasan melekat ini, sehingga tugas-tugas yang dibebankan kepada bawahan tidak menyimpang dari apa yang telah ditetapkan."

Menurut Handoko (2014: 361-362) ada tiga tipe pengawasan, yaitu

1. Pengawasan pendahuluan,

2. Pengawasan "concurrent", dan

3. Pengawasan umpan balik.

Dari uraian di atas dapat dijelaskan sebagai berikut:

1) Pengawasan Pendahuluan (feedforward control).

Dirancang untuk mengantisipasi masalahmasalah atau penyimpanganpenyimpangan dari standar atau tujuan dan memungkinkan koreksi sebelum suatu tahap kegiatan tertentu diselesaikan.

2) Pengawasan yang dilakukan bersamaan dengan pelaksanaan kegiatan (concurrent control). Tipe pengawasan ini merupakan proses dimana aspek tertentu dari suatu prosedur atau syarat harus dipenuhi dulu sebelum kegiatan dilanjutkan.

3) Pengawasan Umpan Balik (feedback control).

Untuk mengukur hasil-hasil dari suatu kegiatan yang telah diselesaikan.

Menurut Siagian (2012: 259260) untuk mengetahui dengan jelas 
apakah penyelenggaraan berbagai kegiatan operasional sesuai dengan rencana atau tidak, dan apakah terjadi deviasi atau tidak, manajemen perlu mengamati jalannya kegiatan operasional tersebut. Berbagai teknik yang dapat digunakan antara lain adalah:

1) Pengamatan langsung atau observasi oleh manajemen untuk melihat sendiri bagaimana caranya para petugas operasional menyelenggarakan kegiatan dan menyelesaikan tugasnya. Teknik ini dapat berakibat sangat positif dalam implementasi strategi dengan efisien dan efektif.

2) Melalui laporan baik lisan maupun tertulis dari para penyelia yang sehari-hari mengawasi secara langsung kegiatan para bawahannya. Dalam semua organisasi, penyampaian laporan dari seorang bawahan kepada atasannya merupakan hal yang bukan hanya biasa terjadi, akan tetapi merupakan keharusan.

3) Melalui penggunaan kuesioner yang respondennya adalah para pelaksana kegiatan operasional.

4) Wawancara. Apabila diperlukan wawancara dengan para penyelenggara berbagai kegiatan operasional pun dapat dilakukan dalam rangka pengawasan.

Menurut Handoko ( dalam Murwaningsih, 2013: 51-52), karakteristik pengawasan yang baik adalah:

1) Akurat.

2) Tepat waktu.

3) Objektif dan menyeluruh.
4) Terpusat pada titik-titik pengawasan strategi.

5) Realistik secara ekonomi.

6) Realistik secara organisasional.

7) Terkoordinasi dengan aliran kerja organisasi.

8) fleksibel.

9) Bersifat sebagai petunjuk dan operasional.

10) Diterima para anggota organisasi.

Menurut Yahya (2006: 135-

137), mengatakan proses pengawasan biasanya terdiri dari lima tahap (langkah). Tahaptahapnya adalah:

1) Penetapan standar pelaksanaan (perencanaan).

2) Penentuan pengukuran pelaksanaan kegiatan.

3) Pengukuran pelaksanaan kegiatan.

4) Pembandingan pelaksanaan dengan standar dan analisa penyimpangan.

5) Pengambilan tindakan koreksi bila diperlukan.

Disiplin kerja adalah suatu alat yang digunakan para manajer untuk berkomunikasi dengan karyawan agar mereka bersedia untuk mengubah suatu perilaku serta sebagai suatu upaya untuk meningkatkan kesadaran dan kesediaan seseorang mentaati semua peraturan perusahaan dan norma-norma sosial yang berlaku (Rivai, 2009: 825).

Disiplin kerja adalah suatu sikap menghormati, menghargai, patuh, dan taat terhadap peraturanperaturan yang berlaku, baik yang tertulis maupun tidak tertulis serta sanggup menjalankannya dan tidak mengelak untuk menerima sanksisanksinya apabila ia melanggar 
tugas dan wewenang yang diberikan kepadanya (Siswanto S., 2005: 291).

Menurut Malayu Hasibuan (2003: 194) indikator-indikator yang mempengaruhi kedisiplinan karyawan suatu organisasi, diantaranya:

1) Tujuan dan kemampuan.

Tujuan dan kemampuan ikut mempengaruhi tingkat kedisiplinan karyawan. Tujuan yang akan dicapai harus jelas dan ditetapkan sevara ideal serta cukup menantang bagi kemampuan karyawan.

2) Teladan pimpinan.

Teladan pimpinan sangat berperan dalam menentukan kedisiplinan kayawan karena pimpinan dijadikan teladan dan panutan oleh para bawahannya.

3) Balas jasa.

Balas jasa (gaji dan kesejahteraan) ikut mempengaruhi kedisiplinan karyawan karena balas jasa akan memberikan kepuasan dan kecintaan karyawan terhadap perusahaann pekerjaannya.

4) Keadilan.

Ikut mendorong terwujudnya kedisiplinan karyawan, karena ego dan sifat manusia yang selalu merasa dirinya penting dan minta diperlakukan sama dengan manusia lainnya.

5) Waskat.

Waskat (pengawasan melekat) adalah tindakan nyata dan paling efektif dalam mewujudkan kedisiplinan karyawan perusahaan.

6) Sanksi hukuman.

Sanksi hukuman berperan penting dalam memelihara kedisiplinan karyawan dengan saanksi hukuman yang semakin berat karyawan akan semakin takut melanggar peraturanperaturan perusahaan sikap dan perilaku indisipliner karyawan akan berkurang.

7) Ketegasan.

Ketegasan pimpinan dalam melakukan tindakan akan mempengaruhi kedisiplinan karyawan perusahaan.

8) Hubungan Kemanusiaan.

Hubungan kemanusiaan yang harmonis di anatara sesama karyawan ikut menciptakan kedisiplinan yang baik pada suatu perusahaan.

Menurut Singodimedjo ( dalam Edy Sutrisno, 2009: 89-92) mengatakan faktor yang mempengaruhi disiplin pegawai adalah:

1) Besar kecilnya pemberian kompensasi

2) Ada tidaknya keteladanan pimpinan dalam perusahaan.

3) Ada tidaknya aturan pasti yang dapat dijadikan pegangan.

4) Keberanian pimpinan dalam mengambil tindakan.

5) Ada tidaknya pengawasan pimpinan.

6) Ada tidaknya perhatian kepada para karyawan.

7) Diciptakan kebiasaan-kebiasaan yang mendukung tegaknya disiplin.

menurut Anwar Prabu (2013: 129-130) mengatakan ada 2 bentuk disiplin kerja, yaitu disiplin preventif, dan disiplin korektif. Adapun penjelasannya adalah sebagai berikut:

a) Disiplin preventif 
Adalah suatau upaya untuk menggerakkan pegawai mengikuti dan mematuhi pedoman kerja, aturan-aturan yang telah digariskan oleh perusahaan.

b) Disiplin korektif

Adalah suatu upaya menggerakkan pegawai dalam menyatukan suatu peraturan dan mengarahkan untuk tetap mematuhi peraturan sesuai dengan pedoman yang berlaku pada perusahaan.

Menurut Rivai (2005: 450451) ada beberapa tingkat dan jenis sanksi pelanggaran kerja yang umumnya berlaku dalam suatu organisasi yaitu:

1) Sanksi pelanggaran ringan, dengan jenis: Teguran lisan, Teguran tertulis, dan pernyataan tidak puas secara tertulis.

2) Sanksi pelanggaran sedang, dengan jenis: Penundaan kenaikan gaji, Penurunan gaji, dan Penundaan kenaikan pangkat.

3) Sanksi pelanggaran berat, dengan jenis: Penurunan pangkat, Pembebasaan dari jabatan, Pemberhentian, dan Pemecatan.

Pabrik Mesin Industri yang beralamat Jl. Raya Madiun Ponorogo Kecamatan Geger merupakan perusahaan yang bergerak dalam bidang pembuatan berbagai macam mesin-mesin industri usaha kecil menengah. Pemilik perusahaan bernama bapak Yunus Wibowo, dan perusahaan ini memiliki 30 orang karyawan yang berasal dari sekitar lingkungan.

Dalam setiap kegiatan yang dilakukan oleh perusahaan perlu ada pegawasan, yang akan mengarahkan para karyawan agar dapat melaksanakan pekerjaan dengan tepat dan sesuai dengan apa yang telah ditetapkan. Agar disiplin kerja dapat tumbuh pada setiap diri karyawan, maka perusahaan harus memperhatikan faktor-faktor yang dapat menimbulkan disiplin kerja diantaranya adalah pengawasan.

Faktor-faktor

yang

mempengaruhi disiplin kerja menurut Singodimedjo (dalam Edy Sutrisno., 2009: 89-92) adalah "besar kecilnya pemberian kompensasi, ada tidaknya keteladanan pimpinan dalam perusahaan, ada tidaknya aturan pasti yang dapat dijadikan pegangan, keberanian pimpinan dalam mengambil tindakan, ada tidaknya pengawasan pimpinan, ada tidaknya perhatian kepada para karyawan dan diciptakan kebiasaankebiasaan yang mendukung tegaknya disiplin."

\section{METODE PENELITIAN}

\begin{tabular}{lcrr}
\multicolumn{2}{c}{ Tempat } & penelitian & ini \\
dilaksanakan & di & Pabrik & Mesin \\
Industri & Kecamatan & Geger \\
Kabupaten & & Madiun & yang
\end{tabular}
beralamatkan Jalan Raya MadiunPonorogo Km. 12. Sebagai bahasan pertimbangan penulis memilih tempat ini karena sebelumnya belum pernah ada penelitian tentang pengaruh pengawasan pimpinan terhadap disiplin kerja karyawan dan data yang diperlukan memenuhi syarat untuk diadakannya penelitian 
serta letak obyek penelitian tidak jauh dari tempat peneliti sehingga diperoleh efektivitas dan efisiensi baik menyangkut waktu, tenaga maupun biaya.

Menurut Hamid Darmadi (2011: 254) desain penelitian adalah "bagian dari perencanaan yang menunjukkan usaha peneliti dalam melihat apakah model testing data yang dilakukan mempunyai validitas yang komprehensif yang mencakup validitas internal maupun ekstenal."

Desain penelitian dalam penelitian ini adalah penelitian konklusif. Menurut Juliansyah Noor (2011: 110), penelitian konklusif merupakan "penelitian yang bertujuan untuk menguji hipotesis." Penelitian konklusif di disain untuk pengambilan keputusan dalam menentukan, mengevaluasi, dan memilih alternatif terbaik dalam memecahkan suatu masalah. Jadi dalam riset dalam disain ini mempunyai tujuan untuk menguji hipotesis dan menguji hubungan dan hasil dan penelitian ini berupa temuan yang digunakan sebagai masukan bagi pembuatan keputusan manajemen.

Dalam penelitian ini menggunakan metode deskriptif yang bertujuan untuk "mendeskripsikan sifat atau karakteristik dari suatu gejala, peristiwa, kejadian yang terjadi saat ini" (Juliansyah Noor, 2011: 111).

Jenis penelitian ini adalah kuantitatif. Penelitian kuantitatif adalah "suatu penelitian yang didasari oleh filsafah positivisme yaitu ilmu yang valid, ilmu yang dibangun dari empiris, teramati terukur, menggunakan logika matematika dan membuat generalisasi atas rerata" ( I Made Wirartha, 2006: 140).

\section{Populasi}

Populasi merupakan objek yang akan diteliti. Menurut Sugiyono, (2013: 119) populasi adalah "wilayah generalisasi yang terdiri atas obyek atau subyek yang mempunyai kualitas dan karakteristik tertentu yang ditetapkan oleh peneliti untuk dipelajari dan kemudian ditarik kesimpulannya.

\section{Sampel}

Adalah bagian dari populasi. Menurut Arikunto, (2010: 174) sampel adalah "sebagian atau wakil populasi yang diteliti." Sampel yang digunakan dalam penelitian ini adalah karyawan Pabrik Mesin Industri yang berjumlah 30 orang.

\section{Teknik Pengambilan Sampel}

Teknik pengambilan sampel yang dilakukan peneliti dalam penelitian ini adalah Sampling Jenuh. Menurut Sugiono (2013: 126) sampling jenuh adalah "teknik penentuan sampel bila semua anggota populasi digunakan sebagi sempel."

penelitian ini dilakukan untuk mengetahui apakah pengawasan pimpinan mempengaruhi disiplin kerja karyawan.

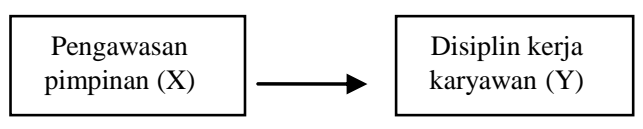

gambar rancangan penelitian 
Menurut Sugiyono (2013 : 61), variabel dalam penelitian dapat dibedakan menjadi :

1. Variabel bebas adalah "variabel yang mempengaruhi atau yang menjadi sebab perubahannya atau timbulnya variabel dependen (terikat)". Variabel bebas (X) dalam penelitian ini adalah Pengawasan Pimpinan.

2. Variabel terikat adalah "variabel yang dipengaruhi atau yang menjadi akibat, karena adanya variabel independen (bebas)". Variabel terikat (Y) dalam penelitian ini adalah Disiplin Kerja Karyawan.

Angket yang digunakan dalam penelitian ini berbentuk kuesioner tertutup artinya kuesioner tersebut sudah disediakan jawabannya sehingga responden tinggal memilih jawaban yang tersedia. Jumlah soal dalam kuesioner ini adalah 28 butir soal yang dibagi dalam 2 variabel, dengan perincian soal untuk variable pengawasan pimpinan adalah 12 dan 16 soal untuk variable disiplin kerja karyawan.

Selanjutnya untuk jumlah dan indikator soal dapat dilihat pada instrumen penelitian. Dokumentasi yang saya maksud dalam penelitian ini adalah dokumentasi yang mendukung dalam penelitian ini, yaitu absensi/daftar hadir dari karyawan pada Pabrik Mesin itu sendiri. Sehingga dapat diketahui bagaimana kedisiplinan karyawannya.

Instrumen penelitian adalah "alat atau fasilitas yang digunakan oleh peneliti dalam mengumpulkan data agar pekerjaannya lebih mudah dan hasilnya lebih baik, dalam arti lebih cermat, lengkap, dan sistematis sehingga lebih mudah diolah" (Arikunto, 2010: 203). Instrumen penelitian digunakan untuk mengukur variabel yang diteliti.

Instrumen dalam penelitian ini menggunakan angket dengan skala likert.

Uji instrumen digunakan untuk menguji instrumen yang digunakan yaitu:

1) Uji Validitas

Validitas atau kesahihan adalah "menunjukkan sejauh mana suatu alat ukur mampu mengukur apa yang ingin diukur" (Siregar, 2012: 162).

2) Uji Reliabilitas

"alat untuk mengukur suatu kuesioner yang merupakan indikator dari variabel atau konstruk" (Ghozali, 2013: 47).

Dalam menganalisis data menggunakan analisis linear sederhana. Di mana hanya ada satu variabel $X$ yang mempengaruhi satu variabel Y.

Keterangan untuk masingmasing adalah sebagai berikut:

1. Uji Korelasi

Analisis korelasi product moment berguna untuk menentukan suatu besaran yang menyatakan bagaimana kuat hubungan suatu variabel dengan variabel lain (Usman Rianse dan Abdi, 2012 : 167).

2. Uji F

"Uji F yaitu alat analisis data yang digunakan untuk mengetahui apakah semua variabel bebas secara bersama-sama mempunyai pengaruh yang signifikan terhadap variabel terikatnya (Gabriel Amin Silalahi, 2003: 86)". 


\section{Uji T}

Menurut Grabiel Amin Silahi (2003: 86), "uji t yaitu alat analisis untuk mengetahui apakah variabel bebas secara individual mempunyai pengaruh yang signifikan terhadap variabel terikat".

\section{HASIL PENELITIAN}

dideskripsikan bahwa variabel pengawasan pimpinan dengan jumlah data $(\mathrm{N})$ sebanyak 30 memiliki deskripsi data sebagai berikut: (a) total skor sebesar 1566; (b) Nilai Mean sebesar 52,20; (c) Nilai Median sebesar 53,00; (d) Nilai Modus sebesar 53; (e) standar deviasi sebesar 3,336; (f) Nilai minimum sebesar 45; (g) Nilai maksimum sebesar 58 .

Hasil analisis kuesioner dari 30 karyawan yang berada di atas nilai rata-rata $\geq 52,20$ sebanyak 16 karyawan atau 53,33 \% . Sedangkan yang di bawah rata-rata sebanyak 14 karyawan atau 46,66 \%. Hal ini dapat disimpulkan pengawasan pimpinan di perusahaan "Pabrik Mesin Industri" adalah baik karena 16 karyawan atau 53,33\% berada diatas rata-rata.

$$
\text { dideskripsikan bahwa }
$$

variabel pengawasan pimpinan dengan jumlah data $(\mathrm{N})$ sebanyak 30 memiliki deskripsi data sebagai berikut: (a) total skor sebesar 1654;

(b) Nilai Mean sebesar 55,13; (c) Nilai Median sebesar 54,00; (d) Nilai Modus sebesar 52; (e) standar deviasi sebesar 4,167; (f) Nilai minimum sebesar 49; (g) Nilai maksimum sebesar 64 . hasil analisis kuesioner dari 30 karyawan yang berada diatas nilai rata-rata $\geq 55,13$ sebanyak 12 karyawan atau $40 \%$. Sedangkan yang dibawah rata-rata sebanyak 18 karyawan atau $60 \%$. Hal ini dapat disimpulkan disiplin kerja di perusahaan "Pabrik Mesin Industri" adalah kurang baik karena 18 karyawan atau $60 \%$ berada di bawah rata-rata.

\section{Hasil Uji Regresi}

Berdasarkan perhitungan diatas dapat diperoleh Persamaan Regresi diperoleh hasil $\mathrm{Y}=11,277+0,840$ $X$. Artinya apabila Pengawasan Pimpinan meningkat sebanyak $1 \%$, maka disiplin kerja karyawan akan meningkat sebesar 0,840 apabila faktor lain dianggap tetap.

\section{Hasil Uji Korelasi}

Untuk menguji hipotesis diperoleh $\quad r_{\text {hitung }} \quad(0,6727) \geq r_{\text {tabel }}$ $(0,361)$ berarti ada hubungan pengawasan pimpinan dengan disiplin kerja karyawan pada Pabrik Mesin Industri Kecamatan Geger Kabupaten Madiun.

\section{Hasil Uji Determinasi}

Besarnya pengaruh
pengawasan pimpinan terhadap
disiplin kerja karyawan pada pabrik
mesin industri kecamatan geger
kabupaten madiun sebesar $45,25 \%$
sedangkan 54,75\% dipengaruhi oleh
faktor lain diantaranya besar
kecilnya pemberian kompensasi,
ada tidaknya aturan pasti yang dapat
dijadikan pegangan, keberanian
pimpinan dalam mengambil
tindakan, ada tidaknya perhatian
kepada karyawan dan diciptakan
kebiasaan-kebiasaan yang
mendukung tegaknya disiplin.




\section{Hasil Uji Fisher}

Dari hasil perhitungan uji $\mathrm{f}$ diperoleh nilai $F_{\text {hitung }}$ sebesar 23,14 sedangkan nilai $F_{\text {tabel }}$ dengan jumlah responden 30 dan probabilitas 0,05 sebesar 4,196. Hal ini berarti $F_{\text {hitung }} \geq F_{\text {tabel }}(23,14$ $\geq$ 4,196). Artinya bahwa ada pengaruh antara pengawasan pimpinan terhadap disiplin kerja karyawan pada "Pabrik Mesin Industri" Kecamatan Geger Kabupaten Madiun.

\section{Hasil Uji T}

Dari hasil perhitungan uji $\mathrm{t}$ diperoleh nilai $t_{\text {hitung }}$ sebesar 4,81 , sedangkan nilai $t_{\text {tabel }}$ dengan jumlah responden 30 dan probabilitas 0,05 sebesar 1,701 . Hal ini berarti $t_{\text {hitung }} \geq t_{\text {tabel }}(4,81 \geq$ 1,701). Artinya bahwa ada beda pengaruh antara pengawasan pimpinan terhadap disiplin kerja karyawan pada "Pabrik Mesin Industri” Kecamatan Geger Kabupaten Madiun.

Berdasarkan hasil pengujian hipotesis maka akan diperoleh keputusan tentang pengaruh pengawasan pimpinan terhadap disiplin kerja karyawan, dengan hipotesis awal yang diajukan yaitu :

Ha : Ada pengaruh yang signifikan antara pengawasan pimpinan terhadap disiplin kerja karyawan.

Ho : Tidak ada pengaruh yang signifikan antara pengawasan pimpinan terhadap disiplin kerja karyawan

Dari pengujian hipotesis regresi linier sederhana, uji korelasi, uji $f$, uji $t$, dengan sampel 30 responden dapat diambil keputusan bahwa ada pengaruh yang signifikan antara pengawasan pimpinan terhadap disiplin kerja karyawan pada Pabrik Mesin Industri Kecamatan Geger Kabupaten Madiun.

\section{PENUTUP}

\section{Simpulan}

Berdasarkan analisis data yang diperoleh dari hasil penelitian tentang pengaruh pengawasan pimpinan terhadap disiplin kerja karyawan pada Pabrik Mesin Industri Kecamatan Geger Kabupaten Madiun yang telah dilakukan maka dapat diambil kesimpulan sebagai berikut :

1. Pengawasan pimpinan di perusahaan "Pabrik Mesin Industri" Kecamatan Geger Kabupaten Madiun adalah baik. Hal ini dapat dilihat dari hasil analisis pengawasan pimpinan diatas dapat diketahui hasil analisis kuesioner dari 30 karyawan yang berada diatas nilai rata-rata $\geq 52,20$ sebanyak 16 karyawan atau 53,33\%. Sedangkan yang di bawah ratarata sebanyak 14 karyawan atau 46,66 \%. Hal ini dapat disimpulkan pengawasan pimpinan di perusahaan "Pabrik Mesin Industri" adalah baik karena 16 karyawan atau 53,33 $\%$ berada diatas rata-rata.

2. Disiplin kerja di perusahaan "Pabrik Mesin Industri" Kecamatan Geger Kabupaten Madiun adalah kurang baik. Hal ini dapat dilihat dari hasil analisis disiplin kerja dapat diketahui hasil analisis kuesioner dari 30 karyawan yang berada diatas nilai ratarata $\geq 55,13$ sebanyak 12 
karyawan atau $40 \%$. Sedangkan yang dibawah ratarata sebanyak 18 karyawan atau $60 \%$. Hal ini dapat disimpulkan disiplin kerja di perusahaan "Pabrik Mesin Industri” adalah kurang baik karena 18 karyawan atau $60 \%$ berada di bawah rata-rata.

3. Pengawasan pimpinan mempunyai pengaruh terhadap disiplin kerja karyawan pada perusahan pabrik mesin industri kecamatan geger kabupaten madiun. Hal ini dapat dilihat dari hasil analisis regresi $\mathrm{Y}=$ $11,277+0,840 \mathrm{X}$ artinya apabila pengawasan pimpinan meningkat $1 \%$ maka disiplin kerja karyawan akan meningkat $0,840 \%$, apabila faktor lain dianggap tetap.

Berdasarkan pengujian hipotesis diperoleh hasil :

a. Uji Korelasi, yaitu nilai $r_{\text {hitung }}$ sebesar $\quad 0,6727$ sedangkan $r_{\text {tabel }}$ sebesar 0,361 . Hasil ini berarti bahwa $r_{\text {hitung }} \geq r_{\text {tabel }} \quad(0,6727 \geq$ 0,361). artinya bahwa ada hubungan di pengawasan pimpinan terhadap disiplin kerja karyawan pada perusahaan "Pabrik Mesin Industri” Kecamatan Geger Kabupaten Madiun.

b. Uji F, yaitu $F_{\text {hitung }}$ sebesar 23,14 sedangkan $F_{\text {tabel }}$ sebesar 4,196. Hasil ini berarti $F_{\text {hitung }} \geq F_{\text {tabel }} \quad(23,14 \geq$ 4,196). Artinya bahwa ada pengaruh antara pengawasan pimpinan terhadap disiplin kerja karyawan pada perusahaan "Pabrik Mesin
Industri” Kecamatan Geger Kabupaten Madiun.

c. Uji T, yaitu $t_{\text {hitung }}$ sebesar 4,81 sedangkan $t_{\text {tabel }}$ sebesar 1,701. Hasil ini berarti $t_{\text {hitung }} \geq t_{\text {tabel }}(4,81 \geq 1,701)$. Artinya bahwa ada beda pengaruh antara pengawasan pimpinan terhadap disiplin kerja karyawan pada perusahaan "Pabrik Mesin Industri" Kecamatan Geger Kabupaten Madiun.

\section{Saran}

Berdasarkan hasil penelitian dan analisis data, maka peneliti mengemukakan saran yang mungkin dapat mejadi bahan pertimbangan bagi pembaca. Adapun saran-saran tersebut diantaranya:

1. Bagi Karyawan

Karyawan hendaknya meningkatkan kedisiplinannya dengan cara lebih mentaati peraturan, sadar terhadap peraturan dan memenuhi tanggung jawab karyawan terhadap peraturan Pabrik Mesin Industri.

2. Bagi Perusahaan

Pihak perusahaan lebih mendukung peningkatan disiplin kerja karyawan dengan selalu memberi pengawasan kepada karyawan. Pengawasan yang dilakukan adalah dengan pengamatan atau observasi langsung dan melalui laporan baik lisan maupun tertulis.

3. Bagi Peneliti Selanjutnya

Bagi peneliti selanjutnya, peneliti dapat menambah variabel bebas, karena selain pengawasan kerja masih 
banyak faktor lain yang dapat mempengaruhi disiplin kerja karyawan pada perusahaan pabrik mesin industri seperti, besar kecilnya pemberian kompensasi, ada tidaknya keteladanan pimpinan dalam perusahaan, ada tidaknya aturan pasti yang dapat dijadikan pegangan, keberanian pimpinan dalam mengambil tindakan, ada tidaknya perhatian kepada para karyawan dan diciptakan kebiasaan-kebiasaan yang mendukung tegaknya disiplin.

\section{DAFTAR PUSTAKA}

Ambar Teguh Sulistiyani. 2011. Memahami Good Governanc Dalam Perspektif Sumber Daya Manusia. Yogyakarta: Gava Media

Anwar Prabu Mangkunegara. 2013, Manajemen Sumber Daya Manusia Perusahaan. Bandung: PT Remaja Rosdakarya.

Edy Sutrisno. 2009. Manajemen Sumber Daya Manusia. Jakarta: Prenada Media Group.

Gabriel Amin Silalahi. 2003, Metodologi Penelitian dan Studi Kasus. Sidoarjo: CV Citra Media.

Gouzali Saydam. 2005, Manajemen Sumber Daya Manusia. Jakarta: Djambatan.
Hamid Darmadi. 2011, Metode penelitian Pendidikan. Bandung: CV Alfabeta.

Heidjrachman dan Suad Husnan. 2013, Manajemen Personalia Edisi Keempat. Yogyakarta: BPFE Yogyakarta.

Husein Umar. 2011, Metode Penelitian untuk Skripsi dan Tesis Bisnis Edisi Kedua. Jakarta: Rajawali Press.

I Made Wirartha. 2006, Metodologi Penelitian Sosial Ekonomi. Yogyakarta: CV Andi Offset.

Imam Ghozali. 2013, Aplikasi Analisis Multivariate Dengan Program IBM SPSS 21 Update PLS Regresi. Semarang: UNDIP.

Juliansyah Noor. 2011, Metodologi Penelitian. Jakarta: Prenada Media Group.

Kadar Nurzaman. 2014, Manajemen Perusahaan. Bandung: CV Pustaka Setia.

Malayu S.P. Hasibuan. 2003, Manajemen Sumber Daya Manusia Edisi Revisi. Jakarta: PT Bumi Aksara.

Malayu S.P. Hasibuan. 2014, Manajemen Sumber Daya Manusia Edisi Revisi. Jakarta: PT Bumi Aksara.

Retno Widyaningrum. 2011, Statistika. Yogyakarta: Pustaka Felicha. 
Siswanto Sastrohadiwiryo. 2005, Manajemen Tenaga Kerja Indonesia. Jakarta: PT Bumi Aksara.

Sondang P.Siagian, 2012. Manajemen Stratejik. Jakarta: PT Bumi Aksara.

Sugiyono. 2008, Statistika untuk Penelitian. Bandung: CV Alfabeta.

Sugiyono. 2009, Metode Penelitian Kuantitatif, Kualitatif dan $R$ $\& D$. Bandung: CV Alfabeta.

Sugiyono. 2010, Metode Penelitian Pendidikan Pendekatan Kuantitatif, Kualitatif dan $R$ $\& D$. Bandung: CV Alfabeta.

Sugiyono. 2013, Metode Penelitian Kombinasi. Bandung: CV Alfabeta.

Suharsimi Arikunto. 2010, Prosedur Penelitian Suatu Pendekatan Praktik. Jakarta: Rineka Cipta.

Syofiyan Siregar. 2012, Statistika Deskriptif untuk Penelitian.
Jakarta: PT Raja Grafindo Persada.

T Hani Handoko, 2014. Manajemen Edisi Kedua. Yogyakarta: BPFE-Yogyakarta.

Tri Murwaningsih. 2013, Perencanaan dan Pengawasan. Surakarta: UNS Press 2013.

Usman Rianse dan Abdi. 2012, Metodologi Penelitian Sosial dan Ekonomi (teori dan aplikasi). Bandung: CV Alfabeta.

Veithzal Rivai, 2005. Manajemen Sumber Daya Manusia untuk Perusahaan. Jakarta: PT. Raja Grafindo Persada.

Vithzal Rivai dan Jauvani Sagala, 2009. Manajemen Sumber Daya Manusia Untuk Perusahaan. Jakarta: Rajawali.

Yohannes Yahya. 2006, Pengantar Manajemen. Yogyakarta: Graha Ilmu. 